\title{
HISTORICAL ATTACHMENT OF COLONIAL BUILDING THROUGH COMMUNITY PERCEPTION: CASE STUDY OF MUSEUM FATAHILLAH, KOTA LAMA JAKARTA
}

\author{
Ari Widyati PURWANTIASNING', Saeful BAHRI ${ }^{2}$
}

DOI: 10.21163/GT_2019. 141.30

\begin{abstract}
:
This study aims to identify the extent of the historical attachment of colonial buildings in conservation areas, especially in the Old City of Jakarta. This research is part of a multiyear study that examines historical attachments in conservation areas as the main topic and discusses several case studies. Fatahillah Museum has been taken as a case study which located in the Old City area of Jakarta. The idea of this research is based on the existence of social and cultural phenomena in the community concerning conservation of architecture for historic buildings. The community in Jakarta as a metropolitan city has a direct impact on the implementation of the concept of building conservation. By digging up information from literature and old archives of historic buildings in Jakarta Old Town, as well as collecting data and explained using descriptive qualitative analysis, case studies can be described thoroughly. The results of this study through community perceptions turned out to be able to present a historical level of attachment to colonial buildings, especially the Fatahillah Museum in the Old City District of Jakarta.
\end{abstract}

Key-words: Historical attachment, Historical buildings, Fatahillah Museum, Community perception, Architectural conservation.

\section{INTRODUCTION}

Jakarta Old Town has been regarded as an area of urban heritage in Indonesia which has suffered from the impact of globalization. One of the efforts from the government is to preserve and conserve all historic buildings within the area. The aim is to enhance and upgrade the quality of the historic buildings themselves. Jakarta Old Town District has many historical old buildings within it, from Masjid Luar Batang, Museum Bahari, Pelabuhan Sunda Kelapa, Jembatan Kota Intan, Toko Merah, Museum Bank Mandiri, Museum Seni Rupa dan Keramik, Pasar Ikan, Menara Syah Bandar, Galangan VOC, Stasiun Beos Kota and Museum Fatahillah (Fig. 1). This paper will not discuss all the above historical old buildings but will explore just one of the significant historical old buildings within Jakarta Old Town District (Fig. 2) shows the zoning of Jakarta Old Town District). The significant historical building within Jakarta Old Town district chosen is Fatahillah Museum which has been known as Jakarta Historical Museum. Fatahillah Museum is located at Jalan Taman Fatahillah No. 1, Jakarta and had been used as The City Hall for The VOC in the colonial era (Stadhuis van Batavia).

The local government of Jakarta has designated the Stadhuis as Fatahillah Museum, to preserve the existence of this historical building. By adapting to its new use as a museum,

\footnotetext{
1 Universitas Muhammadiyah Jakarta, Department of Architecture, Jalan Cempaka Putih Tengah 27, Jakarta Pusat, Indonesia, arwityas@yahoo.com

2 Universitas Muhammadiyah Jakarta, Department of Electrical Engineering, Jalan Cempaka Putih Tengah 27, Jakarta Pusat, Indonesia, saefulbahri2003@yahoo.com
} 
this building can be maintained continuously, and it enables sustainable memory from the past for the next generation (Culture and Museum Office, 2007).

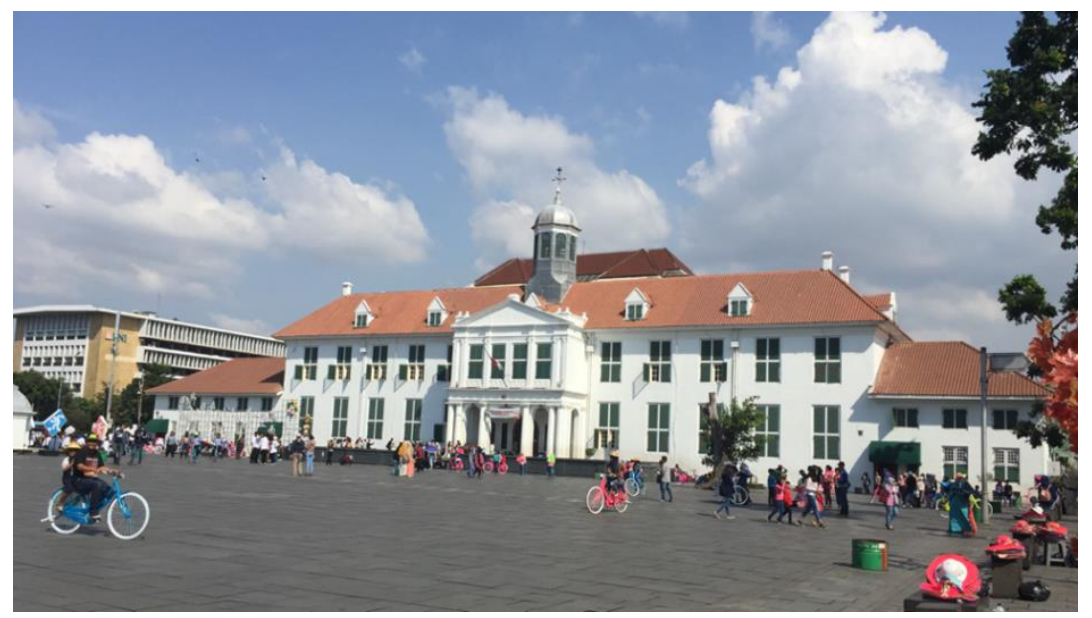

Fig. 1. The Museum Fatahillah under renovation (Purwantiasning, 2015).

This article is a part of research with more than one case studies, with an exploration of some case studies to support the research in answering the question of the study. The idea of this research is based on the existence of social and cultural phenomena within the community concerning historical buildings as well as the historical area. In this case, using Jakarta Old Town District as a case study, the research explores by involved digging out of the information, from archives, documentation and local community perceptions about the existence of historical buildings as well as the historic area, and the impact of the implementation of the concept of conservation and revitalization.

\section{STUDY AREA AND DATA}

Fatahillah Museum is located in Jakarta Province, which is known as an area of Jakarta Old Town. This building used to know as a Stadhuis van Batavia in the colonial era. The Governor of the Dutch used to operate this building as a Governor Office. Figure 2 shows that within Jakarta Old Town District, many colonial buildings have been conserved by the local government of Jakarta. Some of them have been conserved entirely, some of them are still under construction, and some of them still remain the same (the condition is abandoned because of lack of utilities).

Physically, the area of Museum Fatahillah is an area consisting of buildings with colonial architecture (Dutch style). The buildings and area to Jalan Pinangsia have very significant character and are about a hundred years old. According to the history of all the buildings, they have significant history and from past to present, the function of those buildings have been changed from time to time, following the needs of the market. The local government (DKI Jakarta Local Regulation,1999), has been encouraged to maintain all the buildings using their budget for the sustainability of The Jakarta Old Town District which has become a very significant part of the identity of the city. 


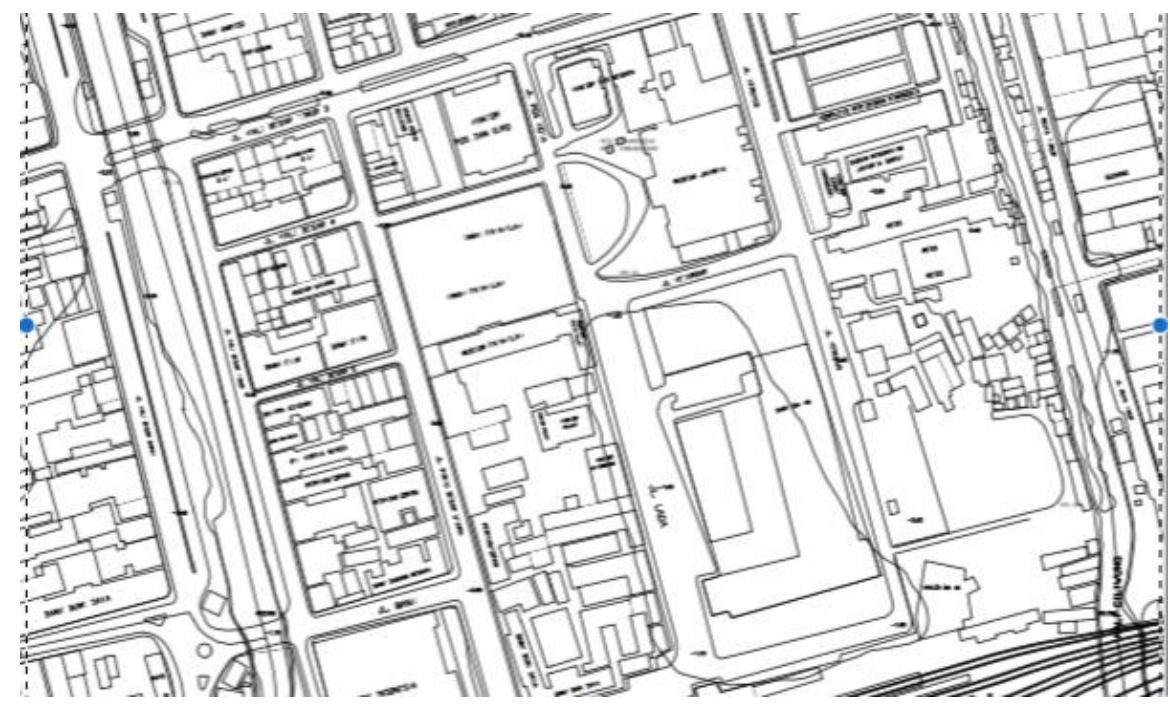

Fig. 2. The area of the Museum Fatahillah (Purwantiasning, 2015).

One of the most significant buildings within The Jakarta Old Town District is The Museum Fatahillah, which has been known as the Historical Museum of Jakarta (Figure 1). This building used to function as The City Hall of The Dutch in The Colonial Era. The character of the building has been maintained to remain the same, and this is to remind people of the past and become a memory for the present generation and future generations.

On the other hand, the area of The Museum Fatahillah has been regarded as one of the tourist destinations, for either domestic or international tourists, because this area has been designated as a historical place (Cagar Budaya) by UNESCO (see Fig. 2). As mentioned by Sauer and Bobkova (2018) that trips to cities represent quite significant part of the global tourism, and urban tourism is considered by United Nations World Tourism Organization (UNWTO) to be an important segment of the international tourism, and as such, it plays a significant role in economic as well as in social environment of many urban destinations. According to Jakarta Tourism Office (2010), the Museum Fatahillah is one of the most significant museums within area Jakarta Old Town. This condition has made the area of The Museum Fatahillah one of the most significant areas within The Jakarta Old Town District, and become the busiest place within the region.

Certain aspects should be fulfilled to reach the criteria's requirement criteria for historic buildings according to UNESCO. This condition has encouraged the local government (DKI JAKARTA Government, 2008) which collaborated with the local Unit Pengelolaan Kawasan to enhance the facilities and services for tourism particularly the infrastructure of the area. Physically, the building of the Museum Fatahillah has the same typology as some government buildings (city hall) in Holland. This existence of The Museum Fatahillah, for sure, will provide a significant atmosphere of colonial architecture as the building in Holland.

The local community, which has the direct impact of the existence of the Museum Fatahillah, will gain some positive effects from the area as a tourist destination. The effects will include some economic, social, cultural and political aspects. All these aspects will be related one to another. 
Visitors to The Museum Fatahillah are not just tourists, but also people from educational institutions such as from elementary schools, secondary schools, junior or senior high schools, or even researchers either local or international, who are interested in gaining more information about the history of The Musem Fatahillah. This condition could enhance the emotional bonding for present or future generations concerning the historic building. For example, the current generation, who never knew the building, will have more experiences after their exploration of The Museum Fatahillah. They will feel the sense of the place and will have some attachment to the building.

This condition could be said to be a historical attachment. The future generation will attach emotionally because of the history of the building. The existence of The Museum Fatahillah that had been used as a government office (city hall) and has an underground prison will give more knowledge to the present generation about how the building was before. The current generation will feel the sense of the building and they would attach the information into their mind and would tell to their generation and on to the future generation, and so on.

Furthermore, the historical attachment would give emotional impact to each person, differently, because the existence of historical buildings will provide different experiences to individuals. For example, when someone has explored The Museum Fatahillah, this person would feel the emotional meaning about the building, maybe this person would feel how it was for all Indonesian people who have lived in the underground prison, whether the Dutch people were working on the upper level of the building of Stadhuis. This emotional attachment also cannot be separated with the culture of the community as well, because both aspects are related to each other, as Herliana (2017) mentioned in her research about cultural attachment.

This emotional attachment could be gained by the existence of the old historical building which has been left from the colonial era, that would make people particularly the local community, think not just about the present day but also about the future. A place becomes essential and significant, if there is an emotional attachment between both the community and the place itself, as Dewiyani (2017) mentioned in previous research. People would understand, that there will not be a future without the existence of the history of the past. This condition could not be separated from the conservation and preservation initiative that should be delivered by the government, either locally or centrally to fulfill the needs of the present and the future generations.

\section{METHODOLOGY}

This research is quantitative research in collecting data and has conducted descriptive qualitative research with a narrative, descriptive approach to describe and analyze the case study in both physical and non-physical aspects. Since the research is historical research, we have studied the historiography and archives that related to the history of Jakarta Old Town District particularly Fatahillah Museum and the surrounded area. We have conducted data collection by spreading 50 questionnaires using google form to identify the level of historical attachment of colonial building through community perception.

\section{RESULTS AND DISCUSSIONS}

In this research, the data obtained from the sample population which has been conducted from 50 questionnaires from the local community of Jakarta. All the respondents 
are various from the age, the occupation, and the educational background. The data have been analyzed by using the statistical method and then interpreted using the knowledge about architectural conservation and historical attachment.

The questions in the questionnaire are gradual which are starting from demographic recognition to the understanding about architectural heritage, architectural conservation and the need for historical attachment to the colonial building. From that data, we have finally concluded and answer the question of this research.

\subsection{Demographic Data}

Demographic data is one of the significant data in this research because, with this data, we can find the various age of the respondents and the gender of the respondents. The knowledge and understanding of architectural heritage as well as architectural conservation is diverse depends on that demographic data. The age of respondents will show the level of education or knowledge of respondents as well as the level of wiseness. The gender of respondents will indicate the level of awareness of this historical attachment matter as well as the level of wiseness.

In this research, we have divided the age range into five classifications below 17 years old, 17-25 years old, 25-40 years old, 40-55 years old and above 55 years old. Fig. 3 shows the variation of the respondent's age. Mostly the respondents are between 17-25 years old, and Fig. 3 shows that this range of ages is about 58,5\%, and has been followed by fourth category 45-55 years old respondent for about 34,1\%. Usually, they are visiting Fatahillah Museum or Fatahillah Square at the weekend. We have seen the area of Fatahillah Square in the weekend, and there are so many teenagers visiting the area of Museum Fatahillah and Fatahillah Square. This place has been regarded as an interesting area with many colonial buildings to be explored, and for teenagers this place is instagrammable.

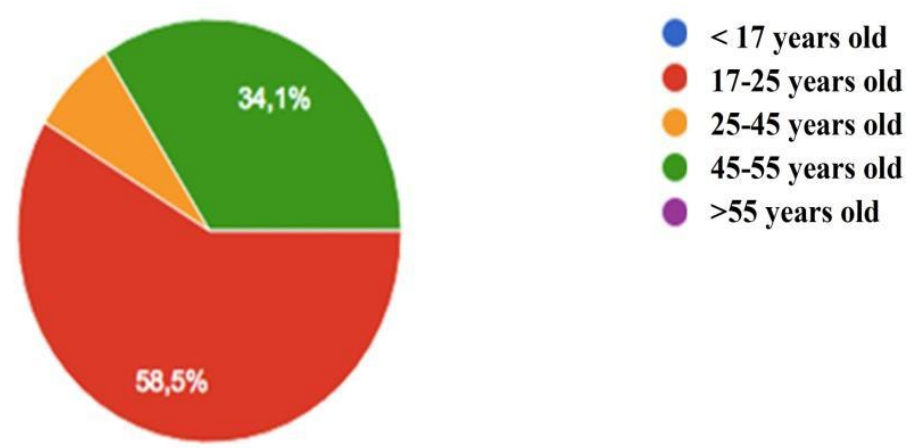

Fig. 3. The variation of respondents by age.

One of preference in choosing a location for a weekend getaway is gender. We have seen directly in the area of Fatahillah Museum and Fatahillah Square, that the visitors of this place have been dominated by the female. And the respondents of this questionnaire mostly are female. From 50 respondents, there are about from $56.5 \%$ female and $43.5 \%$ male. Fig. 4 shows the data of all respondents either male or female. 


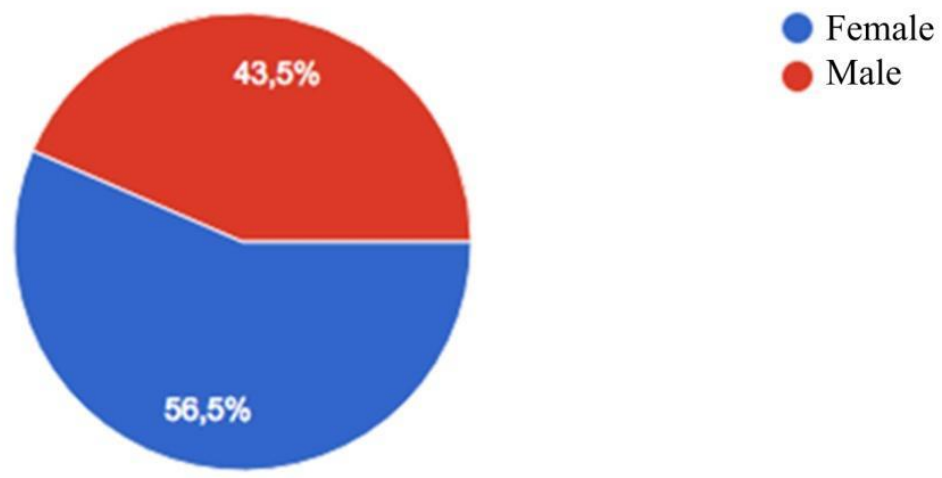

Fig. 4. The variation of respondents by gender.

\subsection{Community Knowledge and Attachment of Fatahillah Museum}

The level of knowledge will show how to extend to which the community eager to learn about the history of the colonial building, particularly in this research is a Fatahillah Museum. The level of knowledge also related to the level of attachment. The higher level of knowledge will indicate as well that the person also has a higher level of attachment of something, in this case, is a colonial building. We have using some data in the questionnaire to identify the level of knowledge as well as the level of attachment of the community to colonial building within Jakarta Old Town, in this case, is Fatahillah Museum. Fig. 5 shows that from 50 respondents there is two respondents do not know what Fatahillah Museum is, this condition shows that in the community of Jakarta there is still some individual who does not know about Fatahillah Museum. But beyond that, there are 48 of the respondents about $97.9 \%$ have very well knowledge about the Fatahillah Museum.

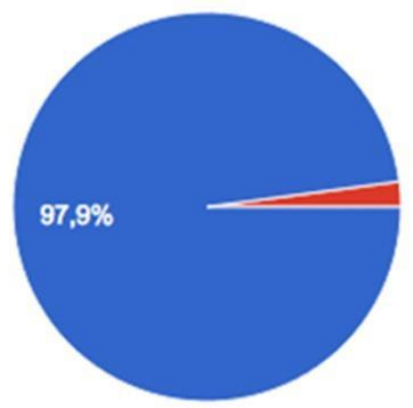

Familiar

Unfamiliar

Fig. 5. The knowledge awareness about Fatahillah Museum.

To support the above data, we have asked about whether the community does know or does not that Fatahillah Museum is one of Cultural Heritage in Indonesia. The answer to the question will show the level of knowledge of the community about the urban heritage particularly Fatahillah Museum as a Cultural Heritage. From 50 respondents, there are 5 respondents who have no knowledge that the Fatahillah Museum is one of Cultural Heritage in Indonesia. It is a bit difficult because the understanding about this matter has 
not been distributed and circulated very well among the community particularly the community of Jakarta. Fig. 6 shows that there are about $89.6 \%$ of the respondents know very well that Fatahillah Museum is one of Cultural Heritage in Indonesia. From the data, it can be concluded that all 45 respondents mostly are students.

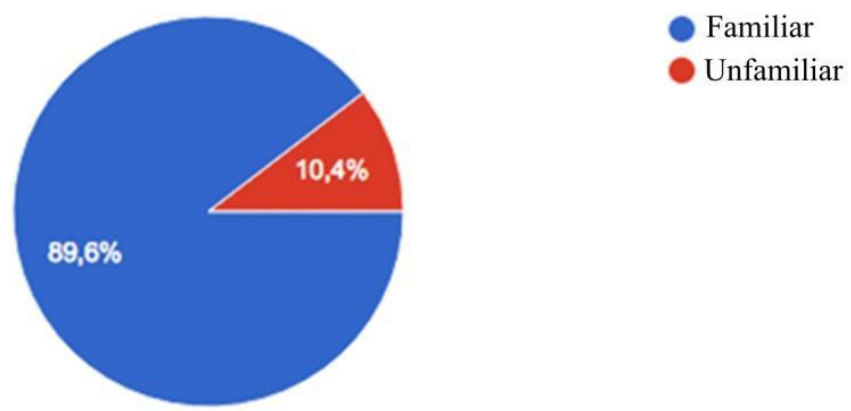

Fig. 6. The knowledge about cultural heritage.

The level of attachment of the community can be seen from how to extend to which respondents will visit the Fatahillah Museum as mention before, that there are some colonial buildings within Jakarta Old Town which have been functioned as a museum. There are Wayang Museum, Bank Indonesia Museum, Bank Mandiri Museum, Museum Bahari or Maritime Museum and Fatahillah Museum. From those four museums, Fatahillah Museum is the most familiar for respondents. From 50 respondents, there are 30 respondents or about $60.4 \%$ choose Fatahillah Museum as their destination (Fig. 7).. Second place is the Bank Indonesia Museum about $16.7 \%$ of respondents who select this destination and has been followed by Wayang Museum about $12.5 \%$ of respondents.
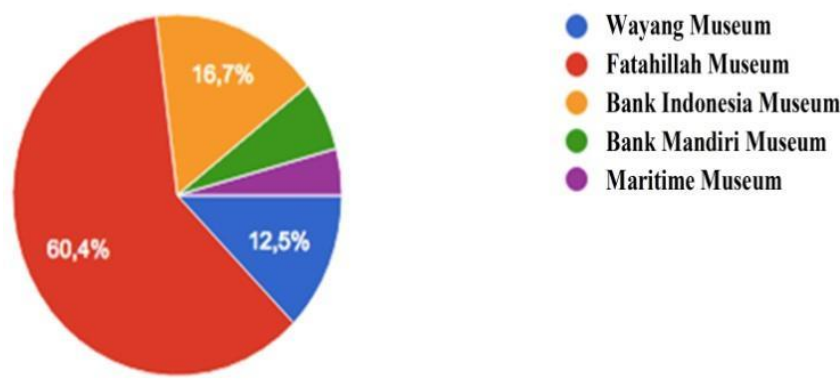

Fig. 7. The destination preference within Jakarta Old Town District.

To support the previous data, we have collected some data from respondents which are related to the preference of the destination. We have divided some category of reason: the historical reason, the building form reason, the atmosphere of the building, and the surrounding environment reason (see Fig. 8). From 50 respondents, there are about $51.1 \%$ have stated that they visit the Fatahillah Museum for all reasons from the historical, the atmosphere and the environment as well. Some of the respondents about $17 \%$ have stated that the historical reason is the most reason they have visited the Fatahillah Museum. 


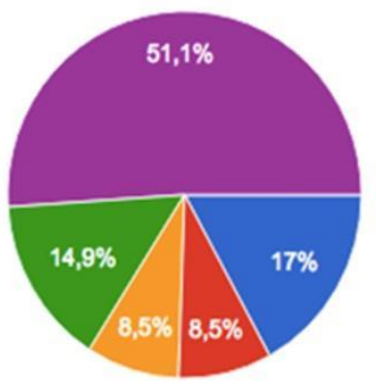

The history of Fatahillah Museum

The architecture of Fatahillah Museum

The stmosphere of Fatahillah Museum

The surrounding environment

All

Fig. 8. The reason of visiting Fatahillah Museum.

To conclude this research, we have delivered the final question to all respondents. The question is about how to extend to which the respondents are willing to know and gain more knowledge about the history of Fatahillah Museum. The answer to this final question will support all the above data completely. Fig. 9 shows that the level of willingness has been divided into 5 levels from the below is level 1, and the higher is indicated by level 5 . From 50 respondents, there are about 19 respondents (38\%) in level 4. And there are $32 \%$ or 16 respondents in level 3, and about 15 respondents or $30 \%$ in level 5. From those data, it can be concluded that the level of historical attachment of 50 respondents could be stated relatively high. All respondents are still having awareness about Cultural Heritage in Indonesia particularly Fatahillah Museum which is a part of Jakarta Old Town District.

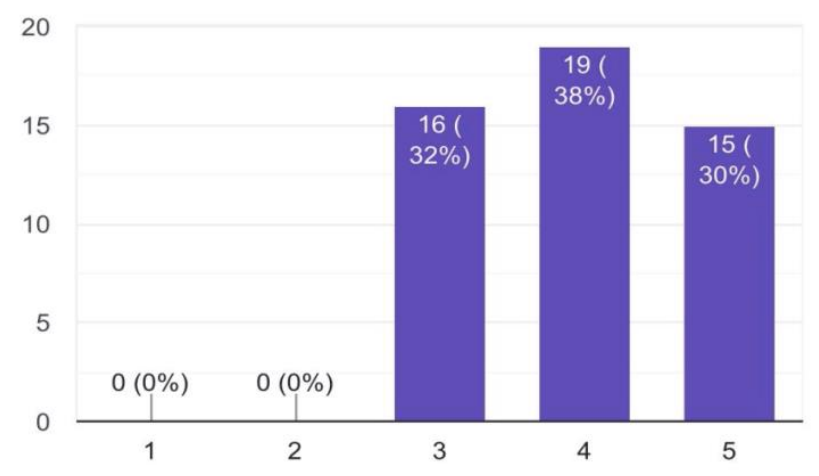

Fig. 9. The level of willingness to gain knowledge about the history of Fatahillah Museum.

\section{CONCLUSIONS}

The need to conserve and preserve old historical buildings has become a significant agenda for local and central government because the existence of old historical buildings helps each generation to be reminded of all the history of the past. If the local government does not have any willingness to conserve and preserve those old historical building, thus 
they will be abandoned. Referring to Tureckova and Nevima (2018), leaving abandoned areas without the effort to find alternative uses for them, regional development is hampered by the fact that it prevents the development of the built-up area, adversely affects the environment and society and has an adverse impact on the entire territorial unit

By presenting the presence of historical old buildings within historical areas and designating historical buildings as conserved buildings, the community will understand and appreciate their existence. This condition will gain and enhance the emotional attachment of people about the presence of historical buildings through their history. Thus the historical attachment of each person could be reached. To obtain historical attachment of historical building in Jakarta Old Town Area particularly Fatahillah Museum, some efforts have been done by the local government:

i) Renovated the Museum and providing a new concept of the Fatahillah Museum

ii) Providing some attraction in the surrounding area of the Fatahillah Museum to attract visitors to come

iii) Using local art and culture to promote the Fatahillah Museum as an icon in Jakarta Old Town

iv) Putting some affiliation to collaborate in promoting the Fatahillah Museum

This research has been completed by analyzing and describing the case study of Fatahillah Museum through community perception. Some results show that community of Jakarta have a strong attachment of the history of Fatahillah Museum; the level of knowledge and attachment also have been identified from the respondents. Furthermore, the research will be developed by exploring the relation between historical attachment and the process of designation of a conservation area and the extent to which historical attachment has a role in the designation of a conservation area.

\section{ACKNOWLEDGEMENTS}

This research is based on several years of research which has now been incorporated, from 2016 to 2019, as part of a multi-years research. This research is a first year research project and the publication in the international conference has been self-funded. We would like to thank all students in the Department of Architecture, Universitas Indonesia for helping this research in distributing and circulating all the questionnaires. And finally, we would like to thank to all local community in Jakarta as respondents for this research as primary sources of this research.

\section{REFERENCES}

Dewiyanti, D. (2017) Historical attachment sebagai daya tarik place: a case study of Masjid Salman, Bandung, Association of Indonesian Built Environmental Researchers. Seminar Heritage 2017 IPLBI.

Culture and Museum Office (2007) Pemerintah Provinsi DKI Jakarta, Book of Jakarta Old Town Guidelines

Jakarta Tourism Office, (2010) Museum Visitor Data based on Kinds of Museum in Jakarta 2010, Jakarta Open Data,

Herliana, E.T., et al. (2017) Cultural Attachment Sebagai Pembentuk Sense of Place Kampung Bugisan Yogyakarta, Association of Indonesian Built Environmental Researchers. Seminar Heritage 2017 IPLBI. 
Hidayati (2009) How to utilize ancient and historic buildings to be worth as a heritage building (undergraduate's thesis). Universitas Indonesia, Jakarta

DKI Jakarta Government (2008) Book of Master Plan Jakarta Old Town, Pemerintah DKI Jakarta.

DKI Jakarta Local Regulation No. 9/1999, Article 8 (1999) about Local Government Regulation about Preservation and Environmental Utilization and Culture Building Heritage, Republik Indonesia.

Purwantiasning, A. W. (2015) Enhancing the quality of environment by creating a concept of revitalization for port area of Sunda Kelapa Jakarta, 6th Seminar of Urban Policies Environmental Land Management for Local and Regional Development. Universidad Nacional del Nordeste, Argentina.

Sauer, M. \& Bobkova, M. (2018) Tourist flows between central european metropolises (in the context of metropolisation processes). Geographia Technica, 13 (2), 125-137.

Tureckova, K. \& Nevima, J. (2018) Perceiving the impact of Brownfields on the Real Estate prices: a case study from four locations in the Czech Republic. Geographia Technica, 13 (2), 138-151. 